\title{
PRZEDSIĘBIORCZOŚĆ NIEROLNICZA WŚRÓD MIESZKAŃCÓW OBSZARÓW WIEJSKICH GMINY PIOTRKÓW KUJAWSKI
}

\author{
Sławomir Zawisza, Agnieszka Paradzińska \\ Zakład Ekonomiki i Doradztwa w Agrobiznesie \\ Uniwersytetu Technologiczno-Przyrodniczego w Bydgoszczy \\ Kierownik Zakładu: prof. dr hab. Sławomir Zawisza
}

\begin{abstract}
Słowa kluczowe: obszary wiejskie, przedsiębiorczość, działalność gospodarcza, ankieta Key words: rural areas, entrepreneurship, economic activity, questionnaire

S y n o p s i s. Na podstawie badania przeprowadzonego w maju i czerwcu 2015 roku wykazano, że z zarejestrowanych 131 podmiotów gospodarczych na podstawie rejestru działalności gospodarczej w analizowanej gminie 21 firm zawiesiło czasowo działalność. $Z$ grupy 110 podmiotów aktywnie prowadzących działalność gospodarczą wybrano 50 przedsiębiorców, wśród których przeprowadzono sondaż. Dzięki badaniom stwierdzono, że przemiany zapoczątkowane w 1989 roku oraz przystąpienie Polski do Unii Europejskiej (UE) w 2004 roku spowodowały największy przyrost liczby podmiotów gospodarczych w gminie Piotrków Kujawski. Najwięcej firm wyrejestrowywano w roku 2011, po pojawieniu się globalnego kryzysu finansowego i gospodarczego. Najczęstszym profilem prowadzonej działalności w gminie Piotrków Kujawski była działalność usługowa (usługi remontowo-budowlane) oraz handlowa (autokomisy oraz sklepy z artykułami spożywczymi i spożywczo-przemysłowymi). Do najważniejszych czynników prorozwojowych respondenci zaliczali: obniżenie podatków oraz oprocentowania kredytów, a także rozwój infrastruktury. Wśród największych trudności badani wymieniali: zbyt wysokie podatki lokalne, niską opłacalność przedsiębiorstwa oraz zbyt wysokie standardy nakładane przez UE.
\end{abstract}

\section{WSTĘP}

Procesy przemian gospodarczych i społecznych, zapoczątkowane w 1989 roku, a następnie kontynuowane poprzez pakiet reform rynkowych $w$ latach 90 . oraz integracja $z$ Unią Europejską (UE) w 2004 roku doprowadziły do znacznego przyspieszenia rozwoju kraju. Jedną z dziedzin, w której odnotowano wyraźny skok rozwojowy, jest sektor gospodarki żywnościowej oraz obszary wiejskie, które otrzymały potężny impuls prorozwojowy dzięki objęciu funduszami UE. Na aktywizowanie pozarolniczych funkcji wsi wpływa pobudzanie przedsiębiorczości, dzięki czemu jest to jeden z najważniejszych sposobów zwiększania szans rozwojowych obszarów wiejskich. Małe i średnie przedsiębiorstwa (MSP) odgrywają bardzo ważną rolę w gospodarce UE. W obrębie Wspólnoty stanowią one 99,8\% wszystkich działających firm, a ich przychody ze sprzedaży kształtują się na poziomie około 56,2\% przychodów ogółem. W MSP zatrudnione jest ponad 75\% siły roboczej. W nowo powstałych firmach, głównie w sektorze handlu i usług, jest tworzonych około 
1/3 miejsc pracy. W tych przedsiębiorstwach jest również wyższy przyrost zatrudnienia niż w dużych firmach [Łuczka-Bakuła, Zyskowska 2006].

Funkcje rolnicze wsi stopniowo tracą na znaczeniu i odgrywają już coraz mniejszą rolę w rozwoju społecznym i ekonomicznym obszarów wiejskich. Coraz bardziej nowoczesne technologie produkcji rolniczej powodują zmniejszenie zapotrzebowania na siłę roboczą. Młodsze pokolenia rodzin rolniczych poszukują pracy poza wsią. Gospodarstwa o małym potencjale produkcyjnym i rozwojowym tracą charakter rynkowy. Część rolników zaprzestaje prowadzenia działalności wyłącznie rolniczej z powodu niskiej opłacalności i rosnącej konkurencji ze strony gospodarstw silniejszych ekonomicznie. Dzięki przedsiębiorczości na obszarach wiejskich możliwa jest aktywizacja mieszkańców wsi oraz poprawa warunków ekonomicznych rolników i ich rodzin. MSP tworzą podstawę wszystkich współczesnych europejskich gospodarek. Dzięki przedsiębiorstwom sektora MSP następuje rozwój gospodarki i wzrost ekonomiczny, a ludność znajduje miejsca pracy [Wasilewski 2012].

W ramach wspólnej polityki rolnej UE odchodzi się w kolejnych perspektywach finansowych od wspierania produkcji rolniczej na rzecz rozwoju obszarów wiejskich. Z budżetu Wspólnoty Polska pozyskuje środki finansowe na rozwój przedsiębiorczości wiejskiej od akcesji w 2004 roku. Kolejne programy wsparcia na lata 2004-2006, 2007-2013 oraz 20142020 pomagają przekształcać wieś i rolnictwo w kraju. Głównie jednakże od aktywności ludności obszarów wiejskich, zależy czy te środki będą możliwe do zdobycia. Innymi formami pomocy państwa w rozwoju nowej działalności gospodarczej są prowadzona polityka fiskalna oraz regulacje za poziomie administracyjno-prawnym towarzyszące przedsiębiorczości. Wpływ na rozwój obszarów wiejskich i rozwój wiejskiej przedsiębiorczości mają także jednostki samorządu terytorialnego oraz instytucje informacyjno-doradcze. Przejawia się to w inwestycjach wpływających na poziom infrastruktury technicznej, która jest czynnikiem wzrostu lokalnej gospodarki i zarazem przekłada się na liczbę działających firm na danym obszarze [Sikorska 2009]. Szczególną rolę mogą odegrać w procesach wsparcia rozwoju przedsiębiorczości bardziej intensywne oddziaływania różnych instytucji, a zwłaszcza wsparcie ośrodków doradztwa rolniczego, które są jedną z najbardziej rozpoznawalnych organizacji w środowiskach wiejskich [Kłodziński 2014, Sieczko, Parzonko 2017].

Polityka wsparcia MSP w UE określona została przez traktat rzymski z 25 marca 1957 roku. Unia Europejska ma możliwość kształtowania polityki rozwoju sektora MSP, podejmowania działań na rzecz podnoszenia poziomu zatrudnienia w państwach członkowskich oraz likwidacji barier ograniczających konkurencyjność sektora MSP. Wśród głównych barier w rozwoju przedsiębiorczości należy wymienić dostrzeganie przez mieszkańców obszarów wiejskich konkurencji w najbliższej okolicy [Żmija 2017]. W ramach polityki rozwoju obszarów wiejskich, na wsparcie dla MSP ma także wpływ Europejska Karta Małych Przedsiębiorstw podpisana w 2000 r., w której podkreślono, że MSP są jednymi z głównych podmiotów w rozwoju gospodarczym UE. Kierunki wsparcia wynikające $\mathrm{z}$ tego dokumentu umożliwiają dokonanie zmian legislacyjnych, procedur administracyjnych i polityki fiskalnej w państwach członkowskich. Są także podstawą dla określania szczegółowych celów realizacji funduszy strukturalnych [Gospodarowicz i in. 2008].

W ramach wspólnej polityki rolnej UE na lata 2014-2020 wspieranie procesów powstawania i rozwijania działalności gospodarczej ma nadal podstawowe znaczenie w rozwoju, a także zwiększaniu konkurencyjności obszarów wiejskich. Pomoc ta realizowana jest w dwojaki sposób - jako wsparcie gospodarstw rolnych i działalności pozarolniczej. Takie podejście daje szansę zarówno rolnikom, którzy mają możliwość dostosowania swych gospodarstw do wymagań rynku, jak i im samym oraz członkom ich rodzin czy innym 
mieszkańcom wsi na tworzenie nowych działalności pozarolniczych [Wasilewski 2012, s. 14]. W opracowaniach dostrzega się regionalne zróżnicowanie działalności pozarolniczej, chociaż dotyczy ono w nieco mniejszym stopniu tego typu aktywności w gospodarstwach rolnych [Czudec, Zając 2017].

Celem badań było zdiagnozowanie rozwoju przedsiębiorczości. Badania objęły głównie osoby niezwiązane z prowadzeniem gospodarstw rolniczych, dotyczyły mieszkańców obszarów wiejskich gminy Piotrków Kujawski. Zakres badań obejmował określenie czynników korzystnych i przeszkód prowadzenia własnej działalności gospodarczej na obszarach wiejskich. W badaniach uwzględniono również proces powstawania i likwidacji firm na terenie gminy Piotrków Kujawski, bowiem ważnym aspektem jest określenie czasu funkcjonowania zarejestrowanych przedsiębiorstw oraz okresów najbardziej intensywnego rejestrowania oraz wyrejestrowywania firm.

\section{METODYKA I ORGANIZACJA BADAŃ}

W celu zrealizowania założeń badawczych konieczne było zapoznanie się z opiniami właścicieli działalności gospodarczych z badanej gminy oraz przeanalizowanie wykazu przedsiębiorstw działających na terenie gminy. Źródłem informacji dotyczących liczby podmiotów gospodarczych występujących na terenie obszarów wiejskich badanej gminy były dokumenty i materiały pochodzące z Urzędu Miasta i Gminy Piotrków Kujawski. Dodatkowo, w maju i czerwcu 2015 roku zostały przeprowadzone badania sondażowe wśród przedsiębiorców z obszarów wiejskich badanej gminy - zarówno właścicieli firm, jak i rolników dodatkowo prowadzących działalność gospodarczą. W badanej gminie w okresie prowadzenia badań zarejestrowanych było 131 przedsiębiorców, w tym 110 aktywnych przedsiębiorców, a 21 tymczasowo zawiesiło działalność. Badaniami ankietowymi objęto 50 przedsiębiorców wybranych w sposób przypadkowy. Maksymalny błąd pomiaru wynosił 8,5\%, przy współczynniku ufności 0,90 i liczebności populacji generalnej 110 osób. Analiza danych z rejestru przedsiębiorstw urzędu gminy i sondaż z wykorzystaniem techniki wywiadu na podstawie kwestionariusza pozwoliły na uzyskanie danych dotyczących aktywności właścicieli zarejestrowanych nierolniczych działalności gospodarczych.

Gmina Piotrków Kujawski jest usytuowana w południowej części województwa kujawsko-pomorskiego w powiecie radziejowskim. Graniczy z gminami: Bytoń, Radziejów, Topólka (powiat radziejowski), Kruszwica (powiat inowrocławski), a także Skulsk i Wierzbinek należącymi do powiatu konińskiego w województwie wielkopolskim. Zajmuje powierzchnię $138,62 \mathrm{~km}^{2}$, podzielona jest na 23 sołectwa. Na terenie gminy zamieszkuje 9426 osób, z czego 4964 osoby (52,7\% ludności) to mieszkańcy obszarów wiejskich [Informator Powiat Radziejowski 2009, s. 12, Ludność... 2015, O gminie... 2015]. Gmina Piotrków Kujawski jest gminą typowo rolniczą, użytki rolne stanowią $82 \%$ powierzchni gminy. Charakteryzują ją dogodne warunki dla rozwoju rolnictwa towarowego, ekologicznego, jak również do uprawy warzyw. Grunty orne w większości zakwalifikowano do IV-VI klasy bonitacyjnej. Głównym kierunkiem produkcji roślinnej są uprawa zbóż, kukurydzy na kiszonkę, buraka cukrowego, rzepaku i warzyw gruntowych. Na terenie gminy znajduje się ponad 1000 gospodarstw rolnych. Wiele $\mathrm{z}$ nich specjalizuje się w produkcji mleka, bydła opasowego, a także trzody chlewnej. Ponadto na terenie gminy znajduje się 885 ha lasów, co stanowi 4\% powierzchni gminy [Informator... 2009, s. 3-4, O gminie... 2015]. 
Wśród badanych osób zdecydowanie przeważali mężczyźni (78\%), natomiast kobiety stanowiły $22 \%$ respondentów. Rozpatrując wiek badanej grupy, można zauważyć, że wśród osób zakładających i prowadzących działalność gospodarczą na terenach wiejskich gminy Piotrków Kujawski przeważały osoby młode - 40\% respondentów między 30. a 39. rokiem życia i 28\% osób do 29 lat. Kolejną grupą pod względem liczebności były osoby w wieku 40-49 lat, które stanowiły $22 \%$ badanych. Najmniej na prowadzenie działalności gospodarczej zdecydowało się osób w wieku 50-59 lat (8\%) i powyżej 60 lat (2\%). Jeśli chodzi o wykształcenie badanej populacji, to $44 \%$ respondentów legitymowało się wykształceniem średnim, a 40\% badanych ukończyło szkoły zawodowe. Wśród badanych 16\% miało wykształcenie wyższe. Kolejnym rozpatrywanym zagadnieniem było posiadanie gospodarstwa rolnego. Zdecydowana większość badanych osób (68\%) zajmowała się jedynie prowadzeniem działalności gospodarczej. Kolejne 10\% pytanych wprawdzie posiadało gospodarstwo rolne, lecz je wydzierżawiło, a głównym ich źródłem dochodu pozostawała prowadzona pozarolnicza działalność gospodarcza. Jedynie $22 \%$ respondentów zadeklarowało prowadzenie gospodarstwa rolnego równolegle z prowadzeniem dodatkowej działalności gospodarczej.

\section{WYNIKI BADAŃ}

Na rysunku 1. zaznaczono lokalizację analizowanych podmiotów gospodarczych. Dosyć duża liczba podmiotów gospodarczych występowała w okolicy miasta Piotrków Kujawski, a więc wokół terenów zurbanizowanych. Wiąże się to z większą możliwością zbytu produkowanych towarów bądź oferowanych usług, a także z ograniczonymi kosztami transportu do potencjalnych klientów. Drugie większe skupisko podmiotów gospodarczych odnotowano w okolicy jeziora Gopło, znajdującego się w zachodniej części gminy. Taka lokalizacja jest dogodna dla działalności turystycznej, w tym agroturystyki, a także dla podmiotów handlowych, rozrywkowych czy transportowych. Analiza położenia badanych podmiotów wskazuje, że większa ich część była zlokalizowana w pobliżu ważniejszych dróg, co wiąże się z lepszą komunikacją i dostępnością usług oraz wszelkich ułatwień w zakresie logistyki. Najmniejsze skupisko przedsiębiorstw odnotowano w południowo-wschodniej części gminy, gdzie występują duże powierzchnie lasów, a zatem są to tereny niezaludnione.

Na podstawie materiałów pozyskanych z Urzędu Miasta i Gminy Piotrków Kujawski określono liczbę zarejestrowanych działalności gospodarczych na terenach wiejskich w latach 1973-2014. W latach 80., kiedy to funkcjonował system gospodarki centralnie sterowanej, powstawało jedynie od 1 do 4 nierolniczych działalności gospodarczych w ciągu roku. Na obszarach wiejskich badanej gminy gwałtowny wzrost liczby podmiotów gospodarczych odnotowano w latach 1988-1991 (rys. 2.). Nastąpiły wówczas zmiany systemowe i przejście do gospodarki rynkowej, co sprzyjało powstawaniu nowych podmiotów. W 1989 r. zarejestrowanych zostało 12 firm, w 1990 r. - 19, a w 1991 r. - 41. W latach 1992-2001 powstawało corocznie średnio 20 nowych. Miało to związek z niestabilną sytuacją ekonomiczną w państwie. Wprawdzie wprowadzano szereg ułatwień dla małych i średnich firm, szczególnie na poziomie prawnym, jednakże równocześnie pojawiło się dużo barier, takich jak np. wysokie oprocentowanie kredytów, wysokie podatki, wzrost konkurencji, niezbyt szybki wzrost zamożności społeczeństwa. W wyniku tego liczba nowo tworzonych podmiotów nie zwiększała się. W kolejnych latach, aż do 2011 r. odnotowano nieznaczny wzrost liczby rejestrowanych podmiotów gospodarczych. Miało to związek z wstąpieniem Polski do UE w 2004 roku. Dzięki wsparciu finansowe- 


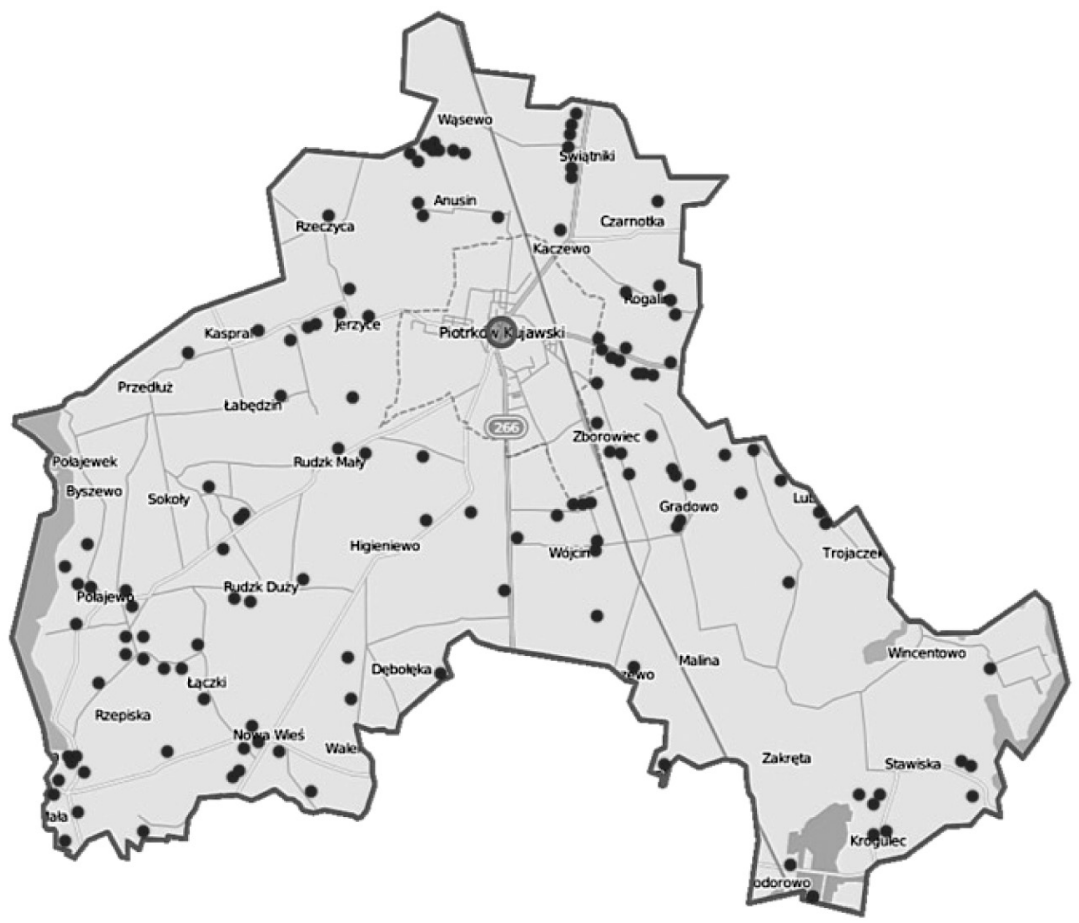

Rysunek 1. Lokalizacja podmiotów działalności gospodarczej na obszarach wiejskich gminy Piotrków Kujawski

Źródło: opracowanie własne na podstawie danych z Urzędu Miasta i Gminy Piotrków Kujawski oraz mapy https://pl.wikipedia.org/wiki/Plik:Piotrk\%C3\%B3w_Kujawski_\%28gmina\%29_ location_map.png (data dostępu: 23.09.2015r.).

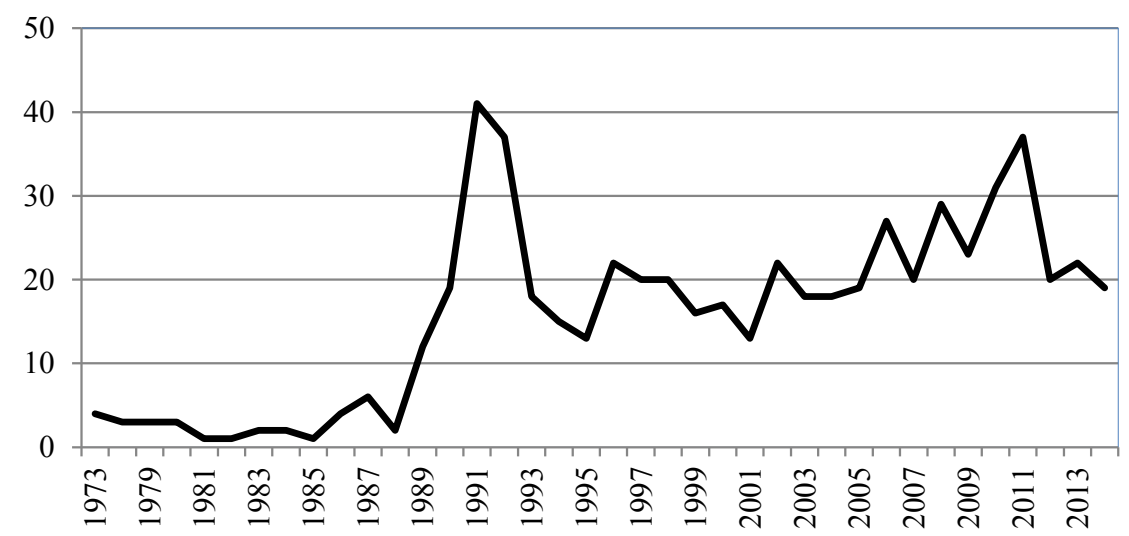

Rysunek 2. Liczba zarejestrowanych działalności gospodarczych na obszarach wiejskich gminy Piotrków Kujawski w latach 1973-2014

Źródło: opracowanie własne na podstawie danych z Urzędu Miasta i Gminy Piotrków Kujawski. 
mu pochodzącemu z funduszy europejskich, kierowanemu na rozwój przedsiębiorczości na terenach wiejskich, zaczęło powstawać więcej nowych podmiotów gospodarczych. W badanej gminie zarejestrowano 18 firm w 2004 r., 27 w 2006 r. oraz 29 w 2009 r. Kolejny dość znaczny wzrost liczby nowych podmiotów odnotowano w $2011 \mathrm{r}$. (37). W latach 2012-2014 zauważalny był postępujący powolny spadek liczby nowych podmiotów (w 2014 r. zarejestrowano 19 firm).

Zmiany liczby wyrejestrowanych podmiotów na terenie obszarów wiejskich gminy Piotrków Kujawski w latach 1989-2014 wskazują, że występowały trzy okresy znacznej redukcji liczby przedsiębiorstw (rys. 3.). Pierwszy wystąpił w latach 1989-1992, czyli w okresie przemian rynkowych i także najbardziej intensywnego procesu powstawania (rejestrowania) nowych firm (w 1992 r. wyrejestrowano 28 podmiotów gospodarczych). Kolejny nastąpił w latach 1997-1999 (w 1999 r. - zlikwidowano 30 podmiotów). W latach 2004-2007 liczba likwidowanych działalności była stabilna (wyrejestrowywano wtedy 2224 firmy). Zapewne miała na to wpływ polityka wsparcia pochodząca z Unii Europejskiej. Jednakże najwięcej podmiotów gospodarczych zakończyło działalność w 2011 r. (aż 60 firm). W tym samym roku jednak dość dużo zarejestrowano nowych podmiotów. Z przeprowadzonych badań wynika, że w tym czasie funkcjonowały one bardzo krótko (od kilku miesięcy do 2 lat). Osoby rozpoczynały prowadzenie działalności tylko ze względu na chęć pozyskania funduszy pochodzących z UE na rozpoczęcie działalności gospodarczej, lecz ich firmy zbyt długo nie utrzymały się na rynku, gdyż stawały się mało opłacalne. Był to także okres globalnego kryzysu finansowego i gospodarczego, który rozpoczął się w USA, a następnie objął także kraje UE. W 2014 r. wyrejestrowano jedynie 7 podmiotów gospodarczych, więc liczba likwidowanych działalności znacznie obniżyła się.

Struktura czasu funkcjonowania wyrejestrowanych podmiotów gospodarczych na obszarach wiejskich badanej gminy przedstawiała się następująco: $14,5 \%$ wszystkich wyrejestrowanych działalności funkcjonowało do 6 miesięcy, 14,7\% podmiotów - od 6 miesięcy do 1 roku, 14,5\% firm - przez 2 lata, a 13,4\% - ponad 1 rok. A zatem okres funkcjonowania przeważającej większości firm był bardzo krótki. Z przeprowadzonych badań wynika również,

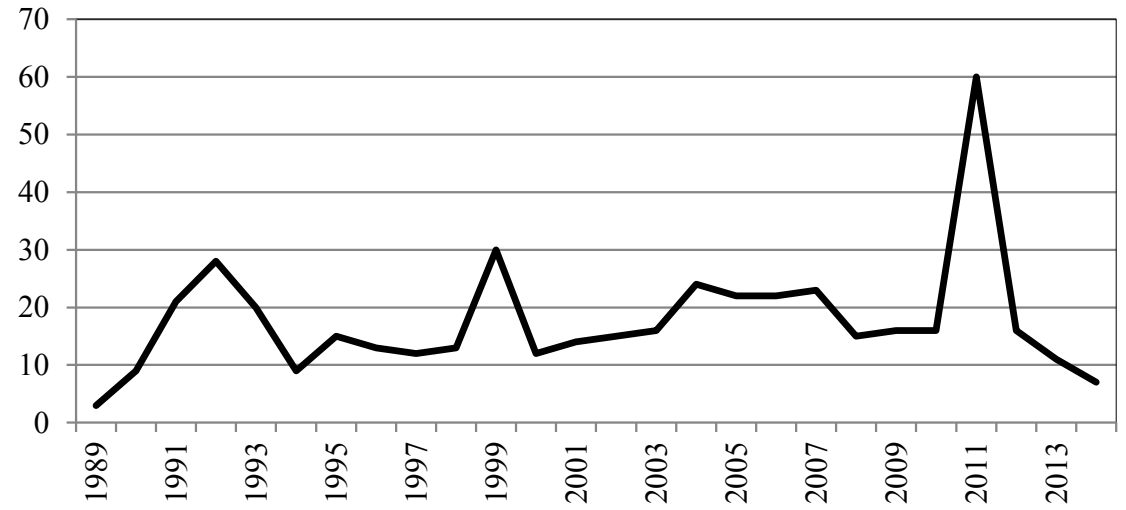

Rysunek 3. Liczba wyrejestrowanych działalności gospodarczych z obszarów wiejskich gminy Piotrków Kujawski w latach 1989-2014

Źródło: opracowanie własne na podstawie danych z Urzędu Miasta i Gminy Piotrków Kujawski. 
że krótko funkcjonujące podmioty powstawały przeważnie w latach 2004-2014. Wpływ na to zjawisko niewątpliwie miało przystąpienie Polski do UE oraz odejście od wsparcia produkcji rolniczej na rzecz pozyskiwania dodatkowych funduszy na rozwój działalności gospodarczej na terenach wiejskich. Niestety prowadzona działalność gospodarcza napotykała na wiele trudności, jak np. konkurencja, niski popyt, mała opłacalność, stąd też właściciele decydowali się na zlikwidowanie firm. Stosunkowo dużo było także firm działających przez 3-10 lat (odpowiednio 8,2-2,0\%). Zdecydowanie najmniej odnotowano podmiotów funkcjonujących na rynku od 11 do 26 lat (1,1-0,4\% wszystkich wyrejestrowanych podmiotów). Najdłużej funkcjonująca firma prowadziła swą działalność przez 32 lata.

Dzięki zgromadzonym materiałom możliwe było określenie struktury pozarolniczej działalności gospodarczej na obszarach wiejskich gminy Piotrków Kujawski. Największym udziałem charakteryzowały się usługi - 64,1\%. Następna pod względem liczebności była działalność handlowa - 21,4\% wszystkich podmiotów. Działalnością produkcyjną zajmowało się jedynie $8,4 \%$ podmiotów, natomiast pozostałe $6,1 \%$ podmiotów trudniło się działalnością mieszaną.

Najdynamiczniej rozwijającą się dziedziną działalności gospodarczej na obszarach wiejskich gminy Piotrków Kujawski była działalność usługowa. Zdecydowanie najwięcej osób oferowało usługi remontowo-budowlane, stanowiły one 36,9\% liczby wszystkich podmiotów usługowych. Związane z remontami były także firmy zajmujące się wylewaniem posadzek czy wykonywaniem instalacji elektrycznych $(3,5 \%)$ i kanalizacyjnych $(3,5 \%)$. Wysoki odsetek stanowiły usługi związane z rolnictwem (10,7\%), jak np. oferowanie usług maszynami rolniczymi, czy związane z chowem zwierząt (inseminacja zwierząt albo korekcja racic). Na obszarach wiejskich badanej gminy funkcjonowały także firmy oferujące usługi: transportowe $(8,3 \%)$, betoniarstwo nagrobkowe $(4,7 \%)$, naprawę i konserwację maszyn rolniczych $(3,5 \%)$ czy pielęgniarstwo $(3,5 \%)$. Najmniej rozpowszechnione były natomiast podmioty zajmujące się usługami tartacznymi, mechaniką pojazdową, naprawą urządzeń elektrycznych, obróbką mechaniczną elementów metalowych, sprzątaniem czy działalnością rozrywkową i edukacją muzyczną (po 2,3\% każde). Spośród innych działalności, które występowały w niewielkim zakresie wymienić można, np. ślusarstwo, stolarstwo, kowalstwo, ubój zwierząt gospodarskich, serwis komputerowy czy usługi pochówkowe.

Firmy handlowe na terenach wiejskich stanowiły $21,4 \%$ wszystkich podmiotów gospodarczych, czyli było ich trzy razy mniej niż w działalności usługowej. Osoby trudniące się handlem na wsiach najczęściej zajmowały się sprzedażą samochodów - autokomisy stanowiły $25,0 \%$ wszystkich podmiotów handlowych oraz prowadziły sklepy z artykułami spożywczymi $(14,3 \%)$ i artykułami spożywczo-przemysłowymi $(10,7 \%)$, co łącznie również stanowiło $25,0 \%$ podmiotów o charakterze handlowym. Duże znaczenie miały również firmy zajmujące się sprzedażą odzieży i obuwia na straganach i targowiskach w okolicznych miastach (14,3\%). Na obszarach wiejskich funkcjonowały także przedsiębiorstwa związane $\mathrm{z}$ handlem materiałami budowlanymi oraz paliwem $(7,1 \%)$, maszynami i urządzeniami rolniczymi (7,1\%), a także handlem obwoźnym $(7,1 \%)$, oferującym artykuły zarówno spożywcze, jak i odzież czy artykuły chemiczno-przemysłowe. Odnotowano także pojedyncze przypadki firm zajmujących się handlem: zwierzętami rzeźnymi, wyrobami tekstylnymi czy sprzętem elektronicznym.

$\mathrm{Na}$ obszarach wiejskich bardzo pożądana z punktu widzenia gospodarczego jest działalność produkcyjna. Stanowi ona źródło dużej liczby nowych miejsc pracy oraz pobudza gospodarkę. Jednak osoby prowadzące nierolniczą działalność gospodarczą na badanym obszarze rzadziej decydowały się na prowadzenie firmy produkcyjnej ze względu na wy- 
magane duże nakłady finansowe podczas tworzenia i rozwoju przedsiębiorstwa, konieczną specjalistyczną wiedzę oraz znaczne ryzyko związane z działaniem firmy. W gminie Piotrków Kujawski tylko co 12. podmiot gospodarczy prowadził działalność produkcyjną. Zdecydowanie najwięcej spośród nich wytwarzało konstrukcje metalowe i ich części (54,5\%), a także produkowało odzież i zajmowało się krawiectwem $(18,2 \%)$. Odnotowano również przedsiębiorstwa wielobranżowe zajmujące się produkowaniem mebli ogrodowych $(9,1 \%)$ oraz wytwarzaniem energii elektrycznej w elektrowni wiatrowej $(9,1 \%)$.

$\mathrm{Na}$ obszarach wiejskich gminy Piotrków Kujawski odnotowano również znikomą liczbę podmiotów o działalności mieszanej (6,1\%). Wśród nich zdecydowanie największe znaczenie miały przedsiębiorstwa usługowo-handlowe (87,5\%), zajmujące się sprzedażą maszyn rolniczych czy drewna oraz usługami transportowymi, oferujące usługi naprawy pojazdów samochodowych czy maszyn, a także oferujące sprzedaż części zamiennych i proponujące kursy nauki jazdy bądź realizujące projekty budowlane. Najmniej było przedsiębiorstw produkcyjno-handlowych, które zajmowały się wytwarzaniem m.in. pokryć dachowych i usługami montażowymi tych elementów (12,5\%).

Z wykonanych badań sondażowych wynika, że do decyzji o założeniu własnej działalności gospodarczej niewątpliwie w dużym stopniu przyczynia się występowanie sprzyjających czynników. Do najbardziej korzystnych działań w opinii respondentów należało obniżenie podatków na wykorzystywane budynki, zajmowany grunt czy związanych z zatrudnianiem pracowników (54\%), a także obniżenie oprocentowania zaciąganych kredytów bankowych (42\%). Duże znaczenie miał także rozwój infrastruktury (22\%), który w dużej mierze zależy od władz gminnych czy powiatowych. Wśród rzadziej wymienianych korzyści znalazły się: bardziej przychylna polityka państwa ukierunkowana na sektor MSP (18\%), zwiększenie popytu na produkowane bądź oferowane dobra czy usługi (16\%), łatwiejszy dostęp do preferencyjnych kredytów (14\%), a także wzrost aktywności władz lokalnych w stosunku do sektora MSP (6\%).

Obok czynników korzystnych, na tworzenie i rozwój nierolniczej działalności gospodarczej, wpływ mają także bariery. Do najczęściej pojawiających się trudności respondenci zaliczyli zbyt wysokie podatki lokalne (48\% odpowiedzi) oraz niską opłacalność prowadzonej działalności (34\%), czyli bariery ekonomiczne. Duże znaczenie badane osoby przypisywały także zbyt wysokim standardom nakładanym przez UE ( $26 \%$ odpowiedzi). Wprawdzie możliwość pozyskania dodatkowych funduszy z UE jest korzystna, jednakże wiąże się to z dużymi wymogami dostosowania się do przepisów i warunków stawianych przez UE. Pozostałe bariery ograniczające tworzenie nowych działalności gospodarczych w opinii respondentów należały do grupy organizacyjno-instytucjonalnej oraz społecznej. Wśród nich wymienić należy brak wsparcia działalności (14\%), brak promocji rynku lokalnego $(6 \%)$, brak klientów zainteresowanych oferowanymi usługami $(6 \%)$ oraz przejawiająca się niechęć sąsiadów bądź znajomych do pojawiającej się konkurencji na rynku (4\%). Należy zaznaczyć, że 10\% respondentów nie zauważyło żadnych trudności podczas rozpoczynania działalności gospodarczej.

\section{PODSUMOWANIE}

Współczesne przemiany wsi i rolnictwa zmierzają w kierunku różnicowania funkcji obszarów wiejskich z tendencjami marginalizowania funkcji rolniczych. Stwarza to nowe wyzwania dla mieszkańców wsi, samorządów zarządzających lokalnymi społecznościami 
oraz ośrodków wspierających przemiany na wsi i w rolnictwie na wszystkich szczeblach organizacyjnych. Wśród najczęściej wskazywanych możliwości działania innych od tradycyjnej działalności rolniczej znajdujemy kształtowanie warunków dla przedsiębiorczości wiejskiej, która uruchamiałaby nierolnicze obszary aktywności mieszkańców wsi.

W badaniach poddano ocenie nierolniczą działalność gospodarczą wśród mieszkańców obszarów wiejskich gminy Piotrków Kujawski. Na podstawie badań należy stwierdzić, że przedsiębiorczość na badanym terenie rozwijała się po wprowadzeniu reform rynkowych oraz po integracji z UE. Z udostępnionych danych można dostrzec występowanie dwóch okresów wzmożonej aktywności mierzonej liczbą podmiotów gospodarczych. Pierwszy dość znaczący wzrost liczby przedsiębiorstw zaobserwowano na początku lat 90. XX wieku, w okresie zmian systemowych w Polsce. Z kolei drugi wystąpił w latach 2002-2011, czyli rozpoczął się w okresie zmian mających związek z wstąpieniem Polski do UE, programami przedakcesyjnymi oraz objęciem Polski wsparciem finansowym po integracji z UE w 2004 roku.

Wśród najczęściej rozwijanych nierolniczych działalności gospodarczych na obszarach wiejskich gminy Piotrków Kujawski były usługi remontowo-budowlane oraz przedsiębiorstwa usługowo-handlowe, jednakże jak wskazuje analiza wyników przeprowadzonych badań, w strukturze rodzajowej w gminie Piotrków Kujawski zdecydowanie najwięcej było działalności usługowych, a następnie handlowych. Najmniejszy odsetek stanowiły działalności produkcyjne oraz mieszane. Pośród podmiotów gospodarczych prowadzących działalność usługową zdecydowanie największy udział miały usługi remontowo-budowlane. Natomiast wśród działalności o charakterze handlowym największym udziałem charakteryzowały się zarówno autokomisy, jak i sklepy z artykułami spożywczymi oraz spożywczo-przemysłowymi. Z kolei wśród podmiotów gospodarczych prowadzących działalność o charakterze mieszanym, przedsiębiorstwa usługowo-handlowe zdecydowanie dominowały, jednakże samych działalności o charakterze mieszanym nie było zbyt dużo w strukturze zarejestrowanych firm. Czas funkcjonowania zarejestrowanych działalności był zwykle krótki, gdyż zdecydowanie najwięcej prowadziło swą działalność od kilku miesięcy do 2 lat. Z kolei wśród działalności aktywnych ponad połowę stanowiły te trwające od roku do 5 lat. Wynika $\mathrm{z}$ tego, że podczas prowadzenia firmy właściciele napotykali na wiele barier utrudniających działalność. Do najważniejszych czynników warunkujących rozwój przedsiębiorczości według respondentów należały: obniżenie podatków oraz oprocentowania kredytów, a także rozwój infrastruktury. Z kolei do najczęściej pojawiających się trudności występujących podczas rozpoczynania działalności gospodarczej badani zaliczyli: zbyt wysokie podatki lokalne, niską opłacalność przedsiębiorstwa oraz zbyt wysokie standardy nakładane przez UE.

Sektor małych i średnich przedsiębiorstw jest kluczowym elementem w rozwoju wsi i ewolucji funkcji obszarów wiejskich w kierunku zmniejszania znaczenia funkcji rolniczych. Działalność gospodarcza staje się coraz ważniejszym źródłem zarobkowania dla ludności wiejskiej, przyczyniając się do wzrostu dochodów mieszkańców wsi, tworzenia nowych miejsc pracy oraz zmniejszania bezrobocia na obszarach wiejskich. Sytuacja dochodowa w rolnictwie skłania również samych rolników do szukania alternatywnego źródła zarobkowania, a prowadzenie gospodarstwa rolnego i działalności gospodarczej pozwala często łączyć obie te działalności. Przedsiębiorczość na obszarach wiejskich powinna być zatem nadal wspierana poprzez programy UE oraz krajowe systemy wsparcia tego sektora gospodarki, ponieważ wpływa on nie tylko na lokalny rozwój gospodarczy, ale jest również ważnym elementem gospodarki krajowej. 


\section{LITERATURA}

Czudec Adam, Zając Dariusz, 2017: Non-farming entrepreneurship in the farm activity diversification process. „Journal Agribusiness Rural Development”, 43(1), s. 69-78.

Gospodarowicz Marcin, Kołodziejczyk Danuta, Wasilewski Adam, 2008: Uwarunkowania rozwoju małych $i$ średnich przedsiębiorstw na obszarach wiejskich. IERiGŻ-PIB, Warszawa, s. 11-15.

Informator Powiat Radziejowski 2009, Wyd. Starostwo Powiatowe, Radziejów.

Kłodziński Marek, 2014: Sektor przedsiębiorczości pozarolniczej na wsi w procesie zrównoważonego rozwoju obszarów wiejskich. „Roczniki Naukowe SERiA”, z. 2, s. 123-128.

Ludność. Stan i struktura ludności oraz ruch naturalny $w$ przekroju terytorialnym. Stan $w$ dniu 31 grudnia 2014 r. GUS. http://stat.gov.pl/obszary-tematyczne/ludnosc/ludnosc/ludnosc-stan-i-struktura-ludnosci-oraz-ruch-naturalny-w-przekroju-terytorialnym-stan-w-dniu-31-xii2014-r-,6,17.html, data dostępu: 23.09.2015 r.

Łuczka-Bakuła Wiesława, Zyskowska Iwona, 2006: Czynniki rozwoju matych i średnich przedsiębiorstw. Wyd. Prodruk, Poznań, s. 7.

Mapa gminy Piotrków Kujawski, https://pl.wikipedia.org/wiki/Plik:Piotrk\%C3\%B3w_Kujawski _\%28gmina\%29_location_map.png, data dostępu: 23.09.2015 r.

O gminie. Serwis UMiG Piotrków Kujawski. http://piotrkowkujawski.pl/kat/id/102, data dostępu: 23.09.2015 r.

Sieczko Anna, Anna J. Parzonko, 2017: Przedsiębiorczość pozarolnicza na obszarach wiejskich w województwie mazowieckim. „Zagadnienia Doradztwa Rolniczego”, nr 1, s. 45-54.

Sikorska Alina (red.), 2009: Rola działalności nierolniczej w kształtowaniu nowych struktur na obszarach wiejskich. Synteza z lat 2005-2009. IERiGŻ PIB, Warszawa, s. 7-9.

Wasilewski Adam (red.), 2012: Wspieranie rozwoju przedsiębiorczości na obszarach wiejskich w ramach Wspólnej Polityki Rolnej 2020. IERiGZ PIB, Warszawa, s. 29, 41-42.

Żmija Katarzyna, 2017: Microeconomic factor of the development of enterprises as perceived by rural entrepreneurs of the Matopolskie Province. „Acta Scientiarum Polonorum. Oeconomia”, 16(1), s. 110-120.

\section{Sławomir Zawisza, Agnieszka Paradzińska \\ NONAGRICULTURAL ENTREPRENEURSHIP AMONG RESIDENTS OF RURAL AREAS OF PIOTRKÓW KUJAWSKI COMMUNITY}

\section{Summary}

The survey was carried out in May and June 2015. As many as 131 business entities chosen on the basis of economic activity registration in the considered commune, 21 of which suspended temporarily their activity, were analyzed. A survey was also carried out among 50 entrepreneurs randomly chosen from a group of 110 business owners involved in economic activity in the rural area of Piotrków Piotrków Kujawski community. The carried out survey revealed that the transformations initiated in 1989 and integration of Poland with the European Union in 2004 caused the highest increase in the number of business entities in Piotrków Kujawski community. The biggest number of unregistered companies was reported in 2011 after occurrence of the worldwide financial and economic crisis. The most common activity profile was in the field of services (renovation and construction) and in trade (used cars dealers, grocery and commodity shops). According to the respondents the most important developmental factors included: reduction of taxes and bank credit interest as well as infrastructural development. The most common difficulties were: too high local taxes, low profitability of business and too high standards imposed by the European Union.

Adres do korespondencji:

Prof. dr hab. inż. Sławomir Zawisza (Kierownik Zakładu)

Uniwersytet Technologiczno-Przyrodniczy

Zakład Ekonomiki i Doradztwa w Agrobiznesie ul. Fordońska 430, 85-790 Bydgoszcz tel. (52) 3408081,3408084 e-mail: zawisza@utp.edu.pl 